DOI: $10.4274 /$ tpa. 1183

\title{
A newborn with subcutaneous nodules
}

\author{
Gülen Tüysüz1, Nihal Özdemir1, Meltem Kıvılcım², Hilal Akı³, Yıldız Perk4, Tiraje Celkan1 \\ ${ }^{1}$ Cerrahpaşa Medical Faculty, Division of Pediatric Hematology and Oncology , Istanbul, Turkey \\ ${ }^{2}$ Cerrahpaşa Medical Faculty, Department of Pediatrics, İstanbul, Turkey \\ ${ }^{3}$ Cerrahpaşa Medical Faculty, Department of Pathology, Istanbul, Turkey \\ ${ }^{5}$ Cerrahpaşa Medical Faculty, Department of Pediatrics, Division of Neanatology, Istanbul, Turkeyv
}

\section{Case}

Our patient who was born in another center with a birth weight of $3920 \mathrm{~g}$ as from the first pregnancy and as the first living child of a 38-year-old mother and a 42-year old father who had no consanguinity. No problem occured during the prenatal follow-up. The APGAR scores for the first and 5th minutes postnatally were assessed to be 9/10. No pathological finding was observed on physical examination. There was no $\mathrm{ABO}$ or Rh incompatibility between the mother and the baby. No additional test was performed in the patient who had a normal birth weight and gestational week. The newborn was compliant with the mother and his nutrition was adequate. After a 24-hour follow-up period the patient was discharged following heel blood sampling for metabolic screening tests. Three days after discharge the patient was brought to our emergency outpatient clinic on the fourth postnatal day with complaints of decreased feeding, malaise and skin eruption which

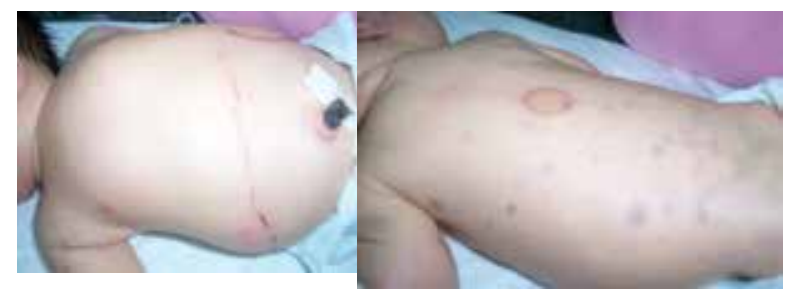

Picture 1. Appearance of the subcutaneous nodules of the patient occured in the last one day. The newborn reflexes were decreased at presentation. The axillary temperature was found to be $38.2^{\circ} \mathrm{C}$, the upper extremity arterial blood pressure was found to be $80 / 40 \mathrm{~mm} \mathrm{Hg}$ and the pulse rate was found to be $162 / \mathrm{min}$. Examination of the respiratory system was found to be normal. There was no pathological finding on examination of the cardiovascular system except for tachycardia. Widespread petechiae and ecchymoses which were prominent on the anterior part of the trunk, marked subcutaneous nodules on the back and hepatosplenomagaly (the liver was palpable $5 \mathrm{~cm}$ below the costal margin in the midclavicular line and the spleen was palpable $4 \mathrm{~cm}$ below the costal margin in the midclavicular line) were found on physical examination. Complete blood count, biochemical tests and coagulation tests were performed. No pathology was found in the biochemical and coagulation tests. Complete blood count was as follows: WBC: $51600 / \mathrm{mm}^{3} \mathrm{Hb}: 12.5 \mathrm{~g} / \mathrm{dL}$, Hct: \% $37 \mathrm{PIt}: 16000 / \mathrm{mm}^{3}$. LDH was found to be $1313 \mathrm{lU} / \mathrm{L}$. 


\section{Diagnosis: Congenital leukemia}

A peripheral blood smear was performed and blasts were observed with a rate of $58 \%$. On bone marrow examination, blasts which were compatible with ALL-L1 in the $F A B$ classification were found with a rate of $70 \%$. High CD 19, CD 22, CD 34, HLA-DR, CD 45 expressions were found in the blast area in the immunophenotyping of the bone marrow. The $C D 10$ value was low. A diagnosis of Pro-B ALL was made in the patient as a result of immunophenotyping and cytochemical examination. ALL-specific translocations were found to be negative in the bone marrow. The pathological examinations of the cerebrospinal fluid obtained by lumbar puncture and skin biopsy samples obtained from the back were evaluated to be compatible with ALL involvement. The "infant leukemia protocol" which is used for ALL patients below the age of one in our clinic was started in the patient. Chemotherapy was discontinued because of sepsis on the $15^{\text {th }}$ day of treatment, but the patient was lost on the 29th day of hospitalization despite supportive treatment.

\section{Discussion}

Multiple cutaneous and subcutaneous nodules may be observed in the newborn period. The majority of these nodules are self-limiting lesions with benign sizes. The differential diagnosis of benign conditions which cause to subcutaneous nodules in the newborn period is shown in Table 1. Nodular lesions in the newborn period may rarely be related with malign diseases. In infancy, nodular involvement related with "infantile myosarcoma" may be observed in the head-neck region and lower extremities (5). The treatment consists of chemotherapy or removal of the

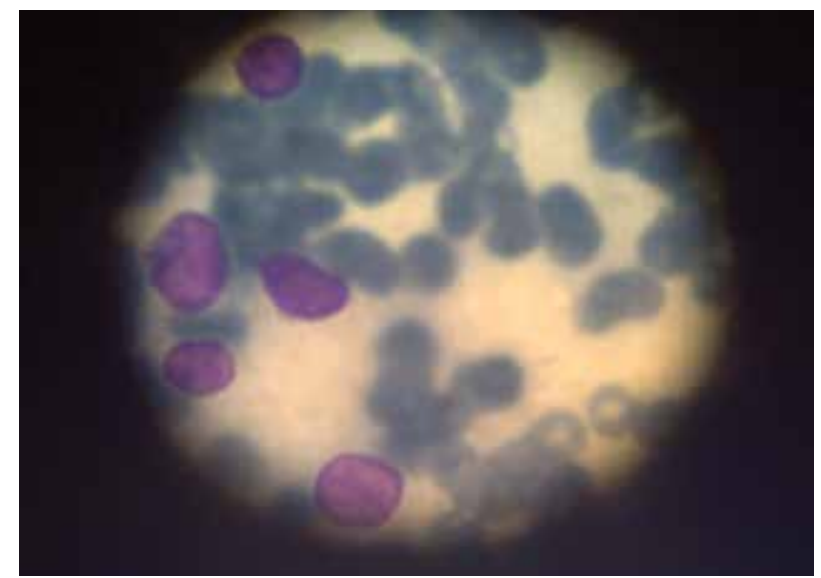

Picture 2. Blasts on the peripheral blood smear of the patient lesion totally by surgery. The nodular primary cutaneous form of rhabdomyosarcoma which shows a substantially malign prognosis may mimic hemangioma by adhering to the skin superficially and the subcutaneous tissue (6). The treatment consists of surgery and chemotherapy. Skin involvement of neuroblastoma which is the most common congenital malign tumor is found in approximately $1 / 3$ of the patients. Skin involvement include solid, painless, nodular, blue-purple colored lesions which can be found widespread in the whole body. Although the prognosis varies according to the stage of the disease, the mainstay of therapy consists of chemotherapy and surgery.

Neonatal or congenital leukemia is defined as leukemia which occurs prenatally (7). It is the second most common malignancy in infants. Depending on the growth rate of the leukemic cells the disease occurs at birth or in the first 4 weeks after delivery (8). It is a very rare disease and constitutes less than $1 \%$ of all childhood leukemias. Its prevalence is 1 per $1-5$ millions live births (9). 200 cases have been reported in the literature until the present time. $80 \%$ of congenital leukemias are myeloid leukemias in contrast to the other childhood leukemias (10). Acute lymphoblastic leukemia constitutes only $20 \%$ of the cases. Most patients with $A L L$ in the newborn period have pro-B ALL and its prognosis is the worst prognosis among all childhood ALLs. The patients present with signs and symptoms including petechiae, purpura, hepatosplenomegaly, lethargy, poor feeding, fever and pallor which are not specific for the newborn period. In $30-50 \%$ of the patients with congenital leukemia, leukemia cutis related with skin infiltration of the immature malign hematopoetic cells is observed in addition to these findings. Skin involvement is the first presentation complaint in $50 \%$ of the patients. Skin involvement may include nodular lesions which are named 'blue berry-muffin' (widespread lesions with varying size which progress from eryhtema to blu-purple nodules) or macules, vesiculopustules and purpura less commonly. Skin involvemetnis mostly observed in AML M-4 and M-5 (11). Congenital leukemia has a poor prognosis (12). In clinics, it should be differentiated especially from bacterial infection with leukomoid reaction, severe hemolysis and severe hypoxia. In addition, it may be confused with congential infection, transient abnormal myelopoesis in Down syndrome and neonatal neuroblastoma because of similar skin findings.

In this article, we presented a patient who presented with subcutaneous nodules in the newborn period and diagnosed with congenital leukemia. Our patient was diagnosed with pro-B ALL which is observed less commonly among congential leukemias. He was lost in the early period because of treatment-related complications. In this article, the differential diagnosis of neonatal subcutaneous nodules and congenital leukemia were discussed. 
Table 1. Benign subcutaneous nodules observed in the newborn period

\begin{tabular}{|c|c|c|c|}
\hline & Patients & Localization-Characteristics & Treatment \\
\hline $\begin{array}{l}\text { Benign subcutaneous fat } \\
\text { necrosis }\end{array}$ & Healthy, term infant & $\begin{array}{l}\text { Cheek, back, gluteal region, arms and } \\
\text { legs } \\
\text { Sharply-circumscribed, indurated nodules } \\
\text { and plaques with varying diameters } \\
\text { Painful when touched }\end{array}$ & $\begin{array}{l}\text { Regresses spontaneously, } \\
\text { no need for treatment }\end{array}$ \\
\hline Sclerema neonatorum & $\begin{array}{l}\text { Especially premature } \\
\text { infants and term infants } \\
\text { with poor general status }\end{array}$ & $\begin{array}{l}\text { Widespread and regional rapidly } \\
\text { spreading, wax-colored indurations in the } \\
\text { skin in the first weeks of life }\end{array}$ & $\begin{array}{l}\text { Disappears with } \\
\text { improvement of the } \\
\text { underlying disease }\end{array}$ \\
\hline Panniculitis (1) & $\begin{array}{l}\text { Neonatal sepsis } \\
\text { (term-preterm) }\end{array}$ & Widespread nodular lesions & $\begin{array}{l}\text { Disappears with } \\
\text { improvement of the } \\
\text { underlying disease }\end{array}$ \\
\hline $\begin{array}{l}\text { Intrauterine infections (2) } \\
\text { (CMV, chickenpox, } \\
\text { toxoplasma, HSV, rubella, } \\
\text { Coxsackie B2) }\end{array}$ & $\begin{array}{l}\text { Affected newborn (term- } \\
\text { preterm) }\end{array}$ & $\begin{array}{l}\text { Maculo-papular,vesicular } \\
\text { Rarely nodular rash }\end{array}$ & $\begin{array}{l}\text { Treatment directed to } \\
\text { disease }\end{array}$ \\
\hline Dermoid cyst & Term-preterm & $\begin{array}{l}\text { Generally a slowly growing single lesion } \\
\text { with a diameter of } 1-4 \mathrm{~cm} \text { and rubber } \\
\text { stiffness having light blue color or the } \\
\text { color of the skin }\end{array}$ & $\begin{array}{l}\text { Should be removed } \\
\text { because of risk of } \\
\text { complication }\end{array}$ \\
\hline Tyroglossal duct cyst & Term-preterm & $\begin{array}{l}\text { A single nodular lesion in the middle area } \\
\text { of the neck }\end{array}$ & $\begin{array}{l}\text { Monitoring, surgery } \\
\text { if infection or skin } \\
\text { fistulization is present }\end{array}$ \\
\hline Branchial cleft cyst & Term-preterm & $\begin{array}{l}\text { A single nodular lesion anterior to the } \\
\text { sternocleidomastoid muscle }\end{array}$ & Surgical excision \\
\hline Deep hemangiomas & $\begin{array}{l}\text { More frequent in preterm } \\
\text { infants and female } \\
\text { infants }\end{array}$ & $\begin{array}{l}\text { Becomes prominent in the second month } \\
\text { after birth } \\
\text { Raised, blue-colored nodular lesion pale } \\
\text { in the center } \\
\text { It may have telengiectasies on the } \\
\text { surface }\end{array}$ & $\begin{array}{l}\text { Compression to vital } \\
\text { organs } \\
\text { Treatment if there is loss } \\
\text { of function or if infection is } \\
\text { present }\end{array}$ \\
\hline Meningiomas (3) & Term-preterm & $\begin{array}{l}\text { Frequent isolated cutaneous lesions in } \\
\text { the head-neck region }\end{array}$ & $\begin{array}{l}\text { Difficult to diagnose, } \\
\text { histopathological diagnosis } \\
\text { is needed, follow-up is } \\
\text { recommended }\end{array}$ \\
\hline $\begin{array}{l}\text { Infantile myofibromatosis } \\
\text { (4) }\end{array}$ & $\begin{array}{l}\text { Term-preterm (single } \\
\text { lesion, more frequent in } \\
\text { male infants) }\end{array}$ & $\begin{array}{l}\text { A single lesion or widespread disease } \\
\text { Mobile, nodular, superficial lesion on an } \\
\text { erythematous background with rubber } \\
\text { stiffness } \\
\text { Generally located in the extremities }\end{array}$ & $\begin{array}{l}\text { Close monitoring of } \\
\text { the lesion if there is no } \\
\text { involvement of internal } \\
\text { organs } \\
\text { Excision if there is } \\
\text { involvement of internal } \\
\text { organs }\end{array}$ \\
\hline Cutaneous mastocytosis & Term-preterm & $\begin{array}{l}\text { Flushing with scratching and rarely } \\
\text { hypotension } \\
\text { Single nodule or multiple nodules }\end{array}$ & $\begin{array}{l}\text { İmproves spontaneously } \\
\text { as the patient gets older }\end{array}$ \\
\hline
\end{tabular}




\section{References}

1. Güneş $T$, Büyükkayhan $D$, Öztürk $F$ Yenidoğanda pseudomonas aeruginosa sepsisine bağlı subkutan nodüller. Türkiye Klinikleri 2006; 15: 169-171.

2. Ukşal Ü. Yenidoğanın sık görülen dermatozları. Klinik Gelişim Dergisi 2009; 22: 1-5.

3. Hussein MR, Abdelwahed AR. Primary cutaneous meningioma of the scalp: a case report and review of literature. J Cutan Pathol 2007; 34: 26-28.

4. Wyatt AJ, Hansen RC. Pediatric skin tumors. Pediatr Clin North Am 2000; 47: 937-963.

5. Russell H, Hicks MJ, Bertuch AA, Chintagumpala M. Infantile fibrosarcoma: clinical and histologic responses to cytotoxic chemotherapy. Pediatr Blood Cancer 2009; 53: 23-27.

6. Megarbane H, Doz F, Manach Y, Fletcher C, Jaubert F, de Prost $Y$, Hamel-Teillac D. Neonatal rhabdomyosarcoma misdiagnosed as a congenital hemangioma. Pediatr Dermatol 2011; 28: 299-301.
7. Badhe PB, Sane SY. Congenital leukemia-organ involvement in six autopsy cases. J Postgrad Med 1992; 38: 127-129.

8. Weinstein HJ. Congenital leukemia and the neonatal myeloproliferative disorders associated with Down's syndrome. Clin Hematol 1978; 7: 147-154.

9. Weitzman S, Grant R. Neonatal oncology: diagnostic and therapeutic dilemmas. Semin Perinatol 1997; 21: 102-111.

10. David GN, Frank AO. Hematology of infancy and childhood. In: acute and chronic myeloproliferative disorders and myelodysplasia. 4th edition. New York: Saunders, 1993: 1288-1218.

11. Torrelo A, Madero L, Mediero IG, Baño A, Zambrano A. Aleukemic congenital leukemia cutis. Pediatr Dermatol 2004; 21: 458-461.

12. Heerema NA, Arthur DC, Sather H, Albo V, Feusner J, Lange BJ, Steinherz PG, Zeltzer P, Hammond D, Reaman GH. Cytogenetic features of infants less than 12 months of age at diagnosis of acute lympho-blastic leukemia: impact of the 11q 23 break-point on outcome: a report of the Childrens Cancer Group. Blood 1994; 83: 2274-2284. 